Introduction and Objectives Chronic Obstructive Pulmonary Disease (COPD) is characterised by expiratory flow limitation contributing to dyspnoea and impacting on exercise capacity and quality of life. Inspiratory muscle training is commonly used to improve inspiratory muscle strength and endurance, exercise capacity and quality of life. The High Frequency Airway Oscillating (HFAO) device uses flow resistance to provide combined inspiratory and expiratory muscle training. It is hypothesised that the use of a HFAO device may improve the strength of the respiratory muscles resulting in reduced sensation of dyspnoea. This study was designed to explore the feasibility of HFAO in COPD.

Methods Patients with symptomatic COPD were included (MRC of $\geq 3$ ). This was a single arm feasibility study using a HFAO device. All participants used the device for $5 \mathrm{~min}, 3$ times per day, for eight-weeks. The primary outcomes were recruitment, attrition and compliance. Self-reported daily diaries identified participants as adherent if they completed $\geq 75 \%$ of device use. Secondary outcome measures included maximal inspiratory and expiratory pressures $\left(\mathrm{Pi}_{\max } /\right.$ $\left.\mathrm{Pe}_{\max }\right)$, Incremental and Endurance Shuttle Walking Tests (ISWT/ESWT) and health related quality of life questionnaires. Data was analysed by a Wilcoxon Signed Rank test and considered statistically significant if $\mathrm{p}<0.05$.

Results 23 participants with COPD were recruited (65\% male, mean [SD] age 65[5] years, $\mathrm{FEV}_{1} \%$ predicted 44[16], FEV1/ FVC ratio 0.46 [0.13]), median [IQR] MRC 4 [3-5], of which 20 participants completed the intervention. $62 \%$ of potential participants were recruited and there was an attrition rate of 13\%. $90 \%$ of participants were considered adherent to device use. A significant improvement in MRC score (median change -1 [IQR 3-3]) was observed ( $\mathrm{p} \geq 0.01)$. Significant improvements were seen in $\mathrm{Pi}_{\max }$ and $\mathrm{Pe}_{\max }$ (table 1). Pre and post intervention exercise performance and quality of life are shown in Table 1.

\begin{tabular}{llll}
\multicolumn{4}{l}{ Abstract P72 Table 1} \\
\hline $\mathrm{n}=20$ & Pre & Post & P value \\
\hline $\mathrm{MRC}$ & $4[3-5]$ & $3[3-3]$ & $>0.01$ \\
$\mathrm{PI}_{\max }\left(\mathrm{cm} \mathrm{H}_{2} \mathrm{O}\right)$ & $59[34-74]$ & $63[42-85]$ & 0.04 \\
$\mathrm{PE}_{\max }\left(\mathrm{cm} \mathrm{H} \mathrm{H}_{2} \mathrm{O}\right)$ & $102[62-125]$ & $110[97-137]$ & $>0.01$ \\
$\mathrm{ISWT}(\mathrm{m})$ & $200[140-260]$ & $240[170-270]$ & 0.68 \\
ESWT (secs) & $170.5[131-247]$ & $203[142-274]$ & 0.51 \\
CRQ dyspnoea & $2.6[2-3]$ & $2.5[2-4]$ & 0.32 \\
LCQ total & $15.71[13-19]$ & $21.5[16-26]$ & 0.14 \\
HADS Anxiety & $6[3-10]$ & $6[3-11]$ & 0.24 \\
HADS Depression & $6[4-10]$ & $5[4-7]$ & 0.19 \\
LCADL total & $32[28-45]$ & $29[23-39]$ & 0.26 \\
CAT Total & $24[18-29]$ & $21.5[16-26]$ & 0.14 \\
CAT Sputum & $3[2-4]$ & $3[2-4]$ & 0.76 \\
\hline
\end{tabular}

Median [IQR] and p-value.

MRC, Medical Research Council dyspnoea score, $\mathrm{PI}_{\max }$ Maximal Inspiratory Pressure; $\mathrm{PE}_{\max \iota}$ Maximal Expiratory Pressure; ISWT, Incremental Shuttle Walking Test; ESWT, Endurance Shuttle Walking Test; CRQ, Chronic Respiratory Questionnaire; LCQ, Leicester Cough Questionnaire; HADS, Hospital Anxiety and Depression Score; LCADL, London Activity of Daily Living, CAT COPD Assessment Test.
Conclusions This shows promising Results in the use of HFAO to reduce dyspnoea within COPD. Recruitment and attrition was appropriate and compliance rates were considered suitable and therefore it is feasible to proceed to a randomised controlled trial.

\section{P73 SYSTEMATIC REVIEW OF THE USE OF PHYSICAL ACTIVITY DEVICES AS AN ADJUNCT TO PULMONARY REHABILITATION IN PATIENTS WITH CHRONIC OBSTRUCTIVE PULMONARY DISEASE}

${ }^{1}$ BL Turner, ${ }^{1} \mathrm{M}$ Kwok, ${ }^{2} \mathrm{AM}$ Wilson. 'Norfolk and Norwich University Hospital, Norwich, UK; ${ }^{2}$ Norwich Medical School, Norwich, UK

\subsection{6/thoraxjnl-2017-210983.215}

Introduction and Objectives Approximately 1.2 million people in the UK are diagnosed with chronic obstructive pulmonary disease (COPD), which costs the NHS over $£ 800$ million per year in direct healthcare costs. Pulmonary rehabilitation (PR) is beneficial in improving health-related quality of life and exercise capacity. It is recommended in guidelines for COPD, however the initial beneficial effects diminish over time. This study reviewed the evidence for using any devices capable of detecting movement as an adjunct to PR, with the aim of prolonging improvements in physical activity (PA).

Methods The MEDLINE and CENTRAL databases were searched for the terms "pulmonary rehabilitation" AND ("COPD" OR "chronic obstructive pulmonary disease") AND ("pedometer" OR "biofeedback" OR "motion detector" OR "movement detector" OR "movement sensor" OR "motion sensor" OR "accelerometer" OR "smartphone"). Studies that met the following criteria were included: (1) adult population (age $\geq 18$ years) undergoing pulmonary rehabilitation, (2) a primary clinical diagnosis of COPD, (3) the use of any device, as defined above, as an adjunct to pulmonary rehabilitation by comparison to a control group. Exclusion criteria were nonEnglish studies and studies for which the full report was inaccessible via the researchers' OpenAthens and Shibboleth logins. Data was extracted and risk of bias assessed by two authors, using the Cochrane Risk of Bias tool.

Results Six studies fulfilled the inclusion criteria, with two showing statistically significant improvements in physical activity levels at the end of follow-up. The other four showed either no statistically significant benefit, or a benefit that was not sustained for the full follow-up period. The studies used a variety of devices, methodologies, and PR programmes. A summary of studies is provided in Table 1.

Conclusions This review has found some evidence that the use of PA measurement devices may be beneficial in augmenting the PA gains achieved following PR, however it is not currently clear how to best calculate PA goals and how important face-to-face feedback is. Further research is therefore required to support the role of such interventions as a long-term intervention for management of COPD. 
Abstract P73 Table 1 Summary of study characteristics

\begin{tabular}{|c|c|c|c|c|c|}
\hline Study & Objectives & Sample and design & Device intervention & Outcome measures & Result \\
\hline 1 & $\begin{array}{l}\text { Determine whether } \\
\text { using pedometers as } \\
\text { an adjunct to PR can } \\
\text { enhance time spent in } \\
\text { at least moderate } \\
\text { intensity PA in people } \\
\text { with COPD }\end{array}$ & $\begin{array}{l}152 \text { participants } \\
\text { recruited from initial } \\
\text { PR assessment. } \\
\text { Randomised into } \\
\text { pedometer ( } n=76 \text { ) and } \\
\text { control }(n=76) \text { groups. } \\
\text { Both underwent } \\
8 \text { weeks' PR. }\end{array}$ & $\begin{array}{l}\text { Pedometer, } \\
\text { individualised daily } \\
\text { step count target (with } \\
\text { weekly review for } \\
8 \text { weeks) and step } \\
\text { count diary during the } \\
\text { PR program and the } \\
\text { following } 6 \text { months }\end{array}$ & $\begin{array}{l}\text { Time spent } \geq 3 \text { METs, daily step } \\
\text { count, Incremental Shuttle Walk Test } \\
\text { (ISWT), Chronic Respiratory } \\
\text { Questionnaire (CRQ) }\end{array}$ & $\begin{array}{l}\text { Intervention did not } \\
\text { enhance mins/ } \\
\text { day } \geq 3 \text { METs }(p=0.16)\end{array}$ \\
\hline 2 & $\begin{array}{l}\text { Investigate the impact } \\
\text { of a PA-focused } \\
\text { behavioural } \\
\text { intervention during and } \\
\text { after a PR programme } \\
\text { on PA levels }\end{array}$ & $\begin{array}{l}32 \text { patients from } 3 \\
\text { primary care centres } \\
\text { and a district hospital. } \\
\text { Randomised into } \\
\text { intervention ( } n=16) \\
\text { and control }(n=16) \\
\text { groups. Both } \\
\text { underwent } 12 \text { weeks' } \\
\text { PR. }\end{array}$ & $\begin{array}{l}\text { Intervention was } \\
\text { during PR with follow- } \\
\text { up support for } \\
3 \text { months after. } \\
\text { Participants completed } \\
\text { a 'Health Contract' } \\
\text { with long-term step- } \\
\text { count goal and } \\
\text { registered daily steps } \\
\text { in a calendar }\end{array}$ & $\begin{array}{l}\text { Daily time in moderate-to-vigorous } \\
\text { PA (MVPA), total daily PA, daily } \\
\text { steps, } 6 \text { min walk test (6MWT), } \\
\text { quadriceps muscle strength, St } \\
\text { Georges Respiratory Questionnaire } \\
\text { (SGRQ), Self-Efficacy Scale }\end{array}$ & $\begin{array}{l}\text { Experimental group } \\
\text { had improved mins/day } \\
\text { at moderate-to- } \\
\text { vigorous PA at } \\
3 \text { months, which } \\
\text { remained improved } \\
\text { after follow-up support } \\
(\mathrm{p}=0.03 \text { ) }\end{array}$ \\
\hline 3 & $\begin{array}{l}\text { Evaluate the effect of } \\
\text { low-intensity exercise } \\
\text { and home-based PR } \\
\text { with or without } \\
\text { feedback of a } \\
\text { pedometer }\end{array}$ & $\begin{array}{l}39 \text { patients randomised } \\
\text { to pedometer }(n=19) \\
\text { and control }(n=20) \\
\text { groups. Both } \\
\text { underwent ongoing } \\
\text { home-based PR. }\end{array}$ & $\begin{array}{l}\text { Pedometer and } \\
\text { monthly feedback } \\
\text { about pedometer use } \\
\text { by PR staff for one } \\
\text { year }\end{array}$ & $\begin{array}{l}\text { Time spent walking/standing/lying, } \\
\text { frequency of postural change, } \\
\text { pulmonary function test, mouth } \\
\text { pressure, quadriceps femoris muscle } \\
\text { force, 6MWT, MRC Dyspnoea Scale, } \\
\text { Body-mass index/airflow Obstruction/ } \\
\text { Dyspnea/Exercise (BODE) index, CRQ }\end{array}$ & $\begin{array}{l}\text { Pedometer group had } \\
\text { greater change in time } \\
\text { spent walking from } \\
\text { baseline to } 1 \text { year later } \\
(p=0.036)\end{array}$ \\
\hline 4 & $\begin{array}{l}\text { Evaluate the effects of } \\
\text { a PA counselling } \\
\text { programme on three } \\
\text { groups of COPD } \\
\text { patients from primary } \\
\text { care, outpatient clinic } \\
\text { and PR }\end{array}$ & $\begin{array}{l}\text { Study randomised } 155 \\
\text { patients in total, } 61 \text { of } \\
\text { whom were from the } \\
\text { PR group into } \\
\text { counselling } \\
\text { ( } \mathrm{n}=78 \text { total, } n=31 \text { from } \\
\text { PR group) and usual } \\
\text { care ( } n=77 \text { total, } \\
n=30 \text { from PR group). } \\
\text { PR group received } \\
9 \text { weeks' exercise } \\
\text { training. }\end{array}$ & $\begin{array}{l}12 \text { weeks' customised } \\
\text { lifestyle PA counselling. } \\
\text { Patients wore a } \\
\text { pedometer all day } \\
\text { during the intervention, } \\
\text { for feedback and } \\
\text { motivation, and kept a } \\
\text { diary of steps taken } \\
\text { and activities other } \\
\text { than steps. }\end{array}$ & $\begin{array}{l}\text { Daily steps, daily PA, spirometry, fat- } \\
\text { free mass, 6MWT, Short Form Health } \\
\text { Survey (SF-36), Clinical COPD } \\
\text { Questionnaire, CRQ, Dutch Exertion } \\
\text { and Fatigue Scale, Hospital Anxiety } \\
\text { and Depression Scale, Perceived } \\
\text { Physical Ability Scale, Self Regulation } \\
\text { Questionnaire for Exercise }\end{array}$ & $\begin{array}{l}\text { PR subgroup } \\
\text { undergoing } \\
\text { intervention had } \\
\text { improved PA at } \\
3 \text { months ( } p=0.030 \text { ) } \\
\text { but not at } 15 \text { months } \\
(p=0.97 \text { ) }\end{array}$ \\
\hline 5 & $\begin{array}{l}\text { Investigate the short- } \\
\text { term effects of a } \\
\text { lifestyle PA counselling } \\
\text { program with feedback } \\
\text { of a pedometer during } \\
\text { standard PR on daily } \\
\text { PA }\end{array}$ & $\begin{array}{l}21 \text { patients entering PR } \\
\text { at rehabilitation centre } \\
\text { were randomised into } \\
\text { experimental }(n=10) \\
\text { and control }(n=11) \\
\text { groups. All patients } \\
\text { followed a regular } \\
9 \text { weeks' PR } \\
\text { programme }\end{array}$ & $\begin{array}{l}\text { Lifestyle counselling } \\
\text { programme ( } 4 \text { sessions } \\
\text { during PR) with } \\
\text { feedback of a } \\
\text { pedometer as a } \\
\text { motivational feedback } \\
\text { tool }\end{array}$ & $\begin{array}{l}\text { Daily PA, chair stand test, arm curl } \\
\text { test, 8-foot up-and-go test, } 2 \text { min } \\
\text { step test, SGRQ, RAND-36, } \\
\text { Groningen Activity Restriction Scale, } \\
\text { Dutch Exertion Fatigue Scale, Beck } \\
\text { Depression Inventory, LIVAS (Dutch } \\
\text { version of Perceived Physical Ability } \\
\text { subscale of the Physical Self-Efficacy } \\
\text { Scale) }\end{array}$ & $\begin{array}{l}\text { Short-term effect of } \\
\text { lifestyle PA counselling } \\
\text { program with feedback } \\
\text { of pedometer was not } \\
\text { significant ( } p=0.38 \text {, } \\
0.24,0.11 \text { for different } \\
\text { measures) }\end{array}$ \\
\hline 6 & $\begin{array}{l}\text { Test the efficacy of an } \\
\text { mHealth intervention } \\
\text { after discharge from PR } \\
\text { at enhancing or } \\
\text { maintaining PA }\end{array}$ & $\begin{array}{l}183 \text { patients from } 32 \\
\text { physiotherapy practices } \\
\text { randomised into } \\
\text { intervention }(n=102 \text { ) or } \\
\text { usual care }(n=81) \text {. All } \\
\text { patients had completed } \\
\text { a PR programme of } \\
3 \text { months within the } \\
\text { past } 6 \text { months }\end{array}$ & $\begin{array}{l}\text { Smartphone application } \\
\text { that displayed PA in } \\
\text { real time with } \\
\text { automated persuasive } \\
\text { messages to achieve } \\
\text { their personalised PA } \\
\text { goal. Physiotherapists } \\
\text { could monitor PA via } \\
\text { website and adjust PA } \\
\text { goals and send group } \\
\text { of individual text } \\
\text { messages }\end{array}$ & $\begin{array}{l}\text { Steps per weekday, METs, } 6 \mathrm{MWT} \text {, } \\
\text { self-administered standardised CRQ }\end{array}$ & $\begin{array}{l}\text { mHealth intervention } \\
\text { did not improve or } \\
\text { maintain PA after a } \\
\text { period of PR ( } \mathrm{p}=0.811 \text {, } \\
0.364 \text { for different } \\
\text { measures) }\end{array}$ \\
\hline
\end{tabular}

